Al-Mashrafiyah: Jurnal Ekonomi, Keuangan dan Perbankan Syariah ISSN (p): 2597-4904 ISSN (e) : 2620-5661

Volume 5, Nomor 1, April (2021), h. 15-33

10.24252/al-mashrafiyah.14503

\title{
Faktor-faktor Yang Mempengaruhi Perkembangan Produk Pembiayaan Pada Bank Pembiayaan Rakyat Syariah di Jawa Timur
}

\author{
Atika Novirda Wenni ${ }^{1}$ \\ Clarashinta Canggih ${ }^{2}$
}

Fakultas Ekonomi Universitas Negeri Surabaya

novirdaatika@gmail.com¹, clarashintacanggih@unesa.ac.id ${ }^{2}$

Received 07-02-2021; Revised: 20-03-2021; Accepted:27-04-2021;

\section{Keywords:}

Analysis, Factor,

Financing, BPRS

\author{
Kata Kunci: \\ Analisis, Faktor, \\ Pembiayaan, Bank \\ Pembiayaan Rakyat \\ Syariab (BPRS)
}

\begin{tabular}{l} 
ABSTRACT \\
\hline This research aimed to analyze the impact of DPK, NPF, FDR, ROA, \\
Inflation and BI Rate to the amount of financing distributed by BPR Syariab in \\
East Java Region under Office of Regional 4 OJK East Java in 2014-2018. It \\
used quantitative research method with the panel data multiple regression \\
approach. The result showed that ROA, Inflation and BI Rate partially bad no \\
significant an effect on the amount of financing channeled by the BPRS, while \\
DPK, NPF, and FDR had an effect on a total of financing by BPRS. \\
Furthermore third party funds, NPF, FDR, RO A, inflation and BI Rate \\
simultaneously had significant effect on the amount of financing channelled by the \\
BPRS. From the results of the study, BPRS needs to increase its receipt of funds \\
from TPF, profitability ratios, and be more selective in providing financing to \\
customers.
\end{tabular}
customers.

Penelitian ini bertujuan untuk menganalisis dampak dari DPK, NPF, FDR, ROA, Inflasi dan BI Rate terhadap jumlah pembiayaan yang disalurkan oleh BPR Syariah di Wilayah Jawa Timur di bawah Kantor Regional 4 OJK Jawa Timur pada 2014-2018. Penelitian ini menggunakan metode penelitian kuantitatif dengan pendekatan regresi berganda data panel. Hasil penelitian menunjukkan ROA, Inflasi dan BI Rate secara parsial tidak berpengaruh signifikan terhadap jumlah pembiayaan yang disalurkan oleh BPRS, sedangkan DPK, NPF, dan FDR berpengaruh terhadap total pembiayaan oleh BPRS. Dana pihak ketiga, NPF, FDR, ROA, inflasi dan BI Rate secara simultan berpengaruh signifikan terhadap jumlah pembiayaan yang disalurkan oleh BPRS. Dari hasil studi, maka BPRS perlu meningkatkan penerimaan dana dari DPK, rasio profitabilitas, serta lebih selektif dalam memberikan pembiayaan kepada nasabah. 


\section{PENDAHULUAN}

Industri perbankan di Indonesia sebagai salah satu industri di sektor keuangan yang mempunyai andil cukup penting pada tatanan sektor perekonomian di Indonesia. Fungsinya sebagai lembaga perantara pada sektor keuangan, bank berperan mengumpulkan dana dari pihak ketiga dan menyalurkannya kembali berupa produk pembiayaan (kredit) kepada nasabah. Terdapat dualisme sistem operasional perbankan di Indonesia, yaitu perbankan yang umum dan perbankan berbasis syariah

Operasional pada perbankan yang berbasis syariah berbeda dengan operasional perbankan konvensional. Bank syariah dalam kegiatan transaksi keuangannya tidak memberikan layanan transaksi yang berbasis sistem bunga bank, sebab bunga bank tidak digunakan pada operasional perbankan syariah karena termasuk kedalam praktik yang haram sebab mengandung riba dan bertentangan dengan prinsip-prinsip Islam. Ismail (2016). Disebutkan pada salah satu ayat dalam Al-Qur'an yaitu pada surah Al-Baqarah ayat 275, bahwa kandungan ayat tersebut telah sesuai dengan misi yang ingin dicapai oleh perbankan syariah untuk menghadirkan keadilan bagi semua pihak dan kemaslahatan bagi masyarakat serta segala bentuk transaksi pada perbankan syariah dilakukan atas dasar sistem bagi hasil.

Perkembangan perbankan syariah di Indonesia cukup pesat sejak kemunculannya, baik dalam hal kelembagaan maupun kepemilikan aset. (Otoritas Jasa Keuangan, 2019. Berdasarkan statistik perbankan syariah bulan September 2019, jumlah Bank Umum Syariah (BUS) mengalami penambahan sampai bulan September tahun 2019 tercatat ada 14 BUS dari 12 BUS pada tahun 2015. Unit Usaha Syariah (UUS) justru berkurang jumlahnya dari 22 UUS tahun 2015 menjadi 20 UUS pada tahun 2019 (Otoritas Jasa Keuangan, 2019). Kepemilikan aset baik BUS dan UUS juga menunjukkan kenaikan dari tahun 2015 hingga 2019. Aset milik BUS dari angka 204.961 miliar rupiah pada tahun 2014 hingga mencapai angka 325.030 miliar rupiah pada tahun 2019. Aset milik UUS juga mengalami peningkatan dari angka 67.383 miliar rupiah tahun 2014 hingga mencapai 165.385 miliar rupiah pada tahun 2019. (Otoritas Jasa Keuangan, 2019).

Berbicara mengenai industri perbankan syariah di Indonesia, selain terdapat BUS dan UUS didalam tatanan kelembagaannya, terdapat pula Bank Pembiayaan Rakyat Syariah (BPRS). BPRS sebagaimana dijelaskan dalam Undang-Undang No 21 Tahun 2008, merupakan salah satu bagian dari bank syariah yang dalam operasionalnya tidak menerima layanan jasa dalam sarana kegiatan pembayaran. Mengacu juga pada peraturan dari lembaga Otoritas Jasa Keuangan (POJK) Nomor 3/POJK.03/2016 yang mengatur tentang Bank Pembiayaan Rakyat Syariah (BPRS), dijelaskan bahwa tujuan dari dibentuknya BPRS adalah untuk bisa memberikan jasa pada sektor perbankan secara cepat, mudah dan sederhana bagi pelaku usaha khususnya pada usaha skala kecil, menengah dan besar. Menjadi bagian dari industri perbankan syariah, kegiatan operasional BPRS juga berbeda dengan operasional Bank Perkreditan Rakyat (BPR) Konvensional. Operasional BPR konvensional dapat berinvestasi pada semua jenis usaha sedangkan BPRS hanya berinvestasi pada usaha yang operasionalnya berdasar pada prinsip syariah.

Perkembangan BPRS di Indonesia dilihat dari kepemilikan asetnya juga menunjukkan trend yang positif. Berdasarkan laporan OJK Bulan September 2019, perkembangan aset yang dimiliki BPRS dari tahun 2015 sampai 2019 dijelaskan pada tabel berikut: 
Tabel 1.1 Perkembangan Kepemilikan Aset BPRS Tahun 2015-2019

\begin{tabular}{clr}
\hline Tahun & \multicolumn{2}{c}{ Kepemilikan } \\
\hline $\mathbf{2 0 1 5}$ & $\mathrm{Rp}$ & $7,739,270.00$ \\
$\mathbf{2 0 1 6}$ & $\mathrm{Rp}$ & $9,157,801.00$ \\
$\mathbf{2 0 1 7}$ & $\mathrm{Rp}$ & $10,840,375.00$ \\
$\mathbf{2 0 1 8}$ & $\mathrm{Rp}$ & $12,361,734.00$ \\
$\mathbf{2 0 1 9}$ & $\mathrm{Rp}$ & $13,315,433.00$ \\
\hline
\end{tabular}

\section{Sumber: Statistik Perbakan Syariah, OJK Bulan September 2019}

Kegiatan operasional BPRS sama seperti halnya kegiatan operasional pada BUS dan UUS, BPR Syariah juga mengalirkan dana kepada masyarakat dalam wujud pembiayaan. Kurun waktu tahun 2015 hingga 2019, total keseluruhan dana untuk pembiayaan yang berhasil didistribusikan oleh BPRS memperlihatkan kenaikan. Kepemilikan aset dan total alokasi dana untuk pembiayaan yang berhasil disalurkan oleh BPRS di Indonesia selama lima tahun terakhir yang menunjukkan peningkatan diikuti pula dengan peningkatan penerimaan (DPK) dalam rentang waktu tahun 20152019. Berikut data jumlah pembiayaan yang disalurkan oleh BPRS dan penerimaan Dana Pihak Ketiga (DPK) selama lima tahun terakhir (2015-2019):

\section{Gambar 1.1 Perkembangan DPK dan Pembiayaan BPRS Tahun 2015-2019}

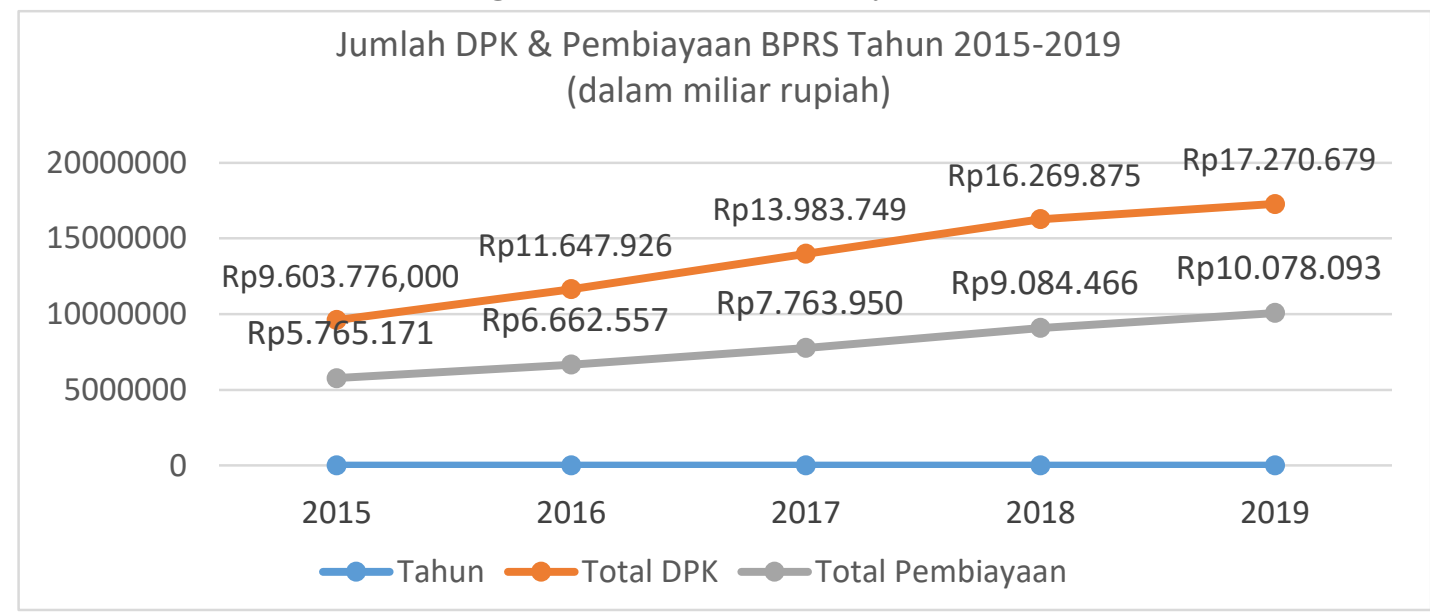

Sumber: Statistik Perbakan Syariah, OJK Bulan September 2019

Islam meninjau bahwa dana-dana yang berhasil dihimpun dari masyarakat oleh bank syariah tersebut dianggap sebagai amanat dari pemilik dana yang diamanatkan pada pihak bank syariah untuk dapat dikelola dengan baik oleh pihak bank. BPRS dalam hal ini dipercaya oleh masyarakat untuk mengemban amanat tersebut. Wujud menjaga amanat tersebut adalah dengan BPRS mengalokasikan dana yang berhasil dihimpun tersebut kepada nasabah untuk kegiatan pembiayaan pada kegiatan usaha produktif. Berdasarkan data yang dijelaskan diatas, jumlah pembiayaan yang diasalurkan BPRS mengalami peningkatan dalam lima tahun terakhir yaitu pada rentang tahun (2015-2019), menunjukkan BPRS telah maksimal dalam upayanya menjalankan amanat mengelola dana-dana tersebut sesuai dengan segala prosedur kebijakan yang dimiliki BPRS.

Kepemilikan aset dan jumlah pembiayaan yang disalurkan meningkat selama lima tahun terakhir, tidak diikuti dengan kualitas dari jumlah lembaga BPRS yang ada dengan baik. Jumlah BPRS dalam dua tahun terakhir antara tahun 2018 sampai September 2019, jumlahnya justru berkurang dari 167 BPRS yang ada tersisa 165 BPRS di seluruh wilayah di Indonesia (Otoritas Jasa Keuangan, 2019).

Penurunan jumlah BPRS di Indonesia dalam dua tahun terakhir, dikarenakan izin usaha operasional BPRS dicabut oleh Otoritas Jasa Keuangan (OJK). Pencabutan izin usaha oleh OJK seperti yang terjadi pada PT. BPRS Hareukat di Provinsi Nanggroe Aceh Darussalam (NAD). Dilansir dari portal berita CNN Indonesia, pencabutan izin usaha yang dilakukan oleh OJK, 
disebabkan PT BPRS Hareukat sebelumnya telah masuk dalam Pengawasan Khusus (BDPK) dikarenakan rasio Kewajiban Penyediaan Modal Minimum (KPMM) yang dimiliki BPRS tersebut kurang dari 0 persen (CNN Indonesia, 2019). Pencabutan izin operasional juga dilakukan oleh OJK karena pihak manajemen BPRS yang tidak kunjung berhasil dalam memperbaiki kinerja perusahaan hingga batas waktu yang telah ditentukan oleh pihak OJK, utamanya untuk kinerja keuangan.

Berdasar pada kasus yang terjadi pada PT. BPRS Hareukat, seluruh BPRS yang masih beroperasi diminta untuk lebih menerapkan prinsip kehati-hatian dalam menyalurkan pembiayaan terutamanya pada produk pembiayaan berbasis bagi hasil kepada nasabah. Rasio kinerja keuangan pada perbankan syariah sendiri disimbolkan dengan rasio Non Performing Finance (NPF), dimana berdasarkan laporan dari Statistik Perbankan Syariah OJK bulan September 2019, NPF pada BPRS dalam lima tahun terakhir yaitu dari tahun 2014 sampai 2019 termasuk kategori tinggi yaitu diatas batas normal 5\%. Rata-rata NPF BPRS dalam lima tahun terakhir sebesar $8.66 \%$ termasuk dalam kategori tinggi. Rasio NPF yang masih tinggi bagi BPRS, dikarenakan banyaknya pembiayaan bermasalah. Pihak bank telah melihat dan menganalisis karakter calon nasabah penerima pembiayaan terlebih dahulu sebelum memutuskan untuk melepaskan dana pembiayaan. Karakter nasabah calon penerima pembiayaan berkaitan dengan watak dan kesanggupan dalam mengembalikan dana pembiayaan tepat pada waktunya sesuai dengan janji yang telah dibuat.

Data OJK tahun 2015 hingga 2019 menunjukkan angka pembiayaan oleh BPRS yang masih terbilang tinggi, menunjukkan pembiayaan masih menjadi operasional dengan pendistribusian dana yang paling banyak dikeluarkan oleh BPRS, maka diperlukan penerapan prinsip kehati-hatian serta perhatian khusus sebelum pihak bank menyalurkannya kembali kepada masyarakat. Kemampuan bank dalam menyalurkan kembali dananya kepada masyarakat harus memperhatikan berbagai faktor, baik faktor dari internal maupun eksternal bank yang turut mempengaruhi kegiatan pembiayaan tersebut. Faktor internal dan eksternal tersebut yang perlu dijadikan pertimbangan pihak BPRS sebelum pengambilan keputusan untuk memberikan dana kepada nasabah pembiayaan.

Aspek dari dalam perusahaan menjadi salah satu yang turut mempengaruhi keseluruhan kegiatan pembiayaan yang dilakukan oleh pihak bank. Faktor internal mencakup aspek likuiditas dan profitabilitas dari perusahaan, menjadi pertimbangan BPRS sebelum melakukan penyaluran pembiayaan kepada nasabah. Aspek likuiditas bank yang dinotasikan dengan Financing to Deposit Ratio (FDR) serta unsur dari profitabilitas bank yang disimbolkan dengan Return On Asset (ROA).

Unsur likuiditas bank yang diwakili oleh FDR yakni rasio antara total dana yang dialirkan pada masyarakat menggunakan dana yang berhasil diperoleh ditambah dengan modal milik bank itu sendiri yang digunakan, turut menjadi pertimbangan bank syariah sebelum memutuskan untuk menyalurkan pembiayaan. (Dendawijaya, 2009). Nilai FDR yang dimiliki bank memperlihatkan bahwa kecil atau buruknya kemampuan dari likuiditas bank. Rasio FDR sendiri juga menggambarkan seberapa baik kemampuan bank dalam melunasi kembali dana yang ditarik untuk alokasi pembiayaan oleh deposan dengan bergantung pada besaran pembiayaan yang telah dialirkan sebagai sumber likuiditas. (Umiyati \& Ana, 2017).

Rasio profitabilitas yang diwakili oleh ROA memperlihatkan kapabilitas perusahaan dalam memanfaatkan semua aktiva yang dimilikinya dalam rangka untuk memperoleh keuntungan bersih perusahaan, turut menjadi pertimbangan BPRS dalam kegiatannya menyalurkan pembiayaan. Bank syariah dituntut untuk mendapatkan profitabilitas bagi perusahaannya dalam mendukung kelancaran kegiatan operasionalnya tanpa terkecuali kegiatan pembiayaan. Islam sendiri memperbolehkan seseorang maupun lembaga untuk mencari keuntungan dalam rangka mendukung operasional usahanya, namun tetap dengan nominal keuntungan yang masih tergolong wajar tidak berlebihan.

Faktor diluar BPRS juga turut berpengaruh terhadap jumlah pembiyaan yang disalurkan. Aspek diluar bank yang dinilai dapat berdampak pada kegiatan pembiayaan oleh BPR Syariah seperti terjadinya inflasi di Indonesia dan suku bunga acuan yang ditetapkan oleh Bank Indoneisa. Terjadinya inflasi dapat berdampak pada dunia usaha. Kemungkinan terburuk yang terjadi yaitu bidang usaha milik masyarakat mendapati penyusutan pendapatan disebabkan turunnya permintaan atau minat membeli dari masyarakat. Penurunan angka pendapatan usaha memungkinkan para 
pelaku usaha tidak dapat mengembalikan dana pembiayaan yang diterimanya, hal tersebut akan turut mempengaruhi penyaluran pembiayaan pada perbankan syariah.

Islam memandang terjadinya inflasi dapat berdampak buruk pada kondisi perekonomian. Terjadinya inflasi turut mendorong masyarakat untuk melakukan investasi pada sesuatu yang sifatnya non produktif seperti melakukan penumpukan kekayaan pada emas, mata uang asing dan lainnya. Penumpukan juga bisa dilakukan pada barang kebutuhan pokok. Upaya penumpukan keduanya yang hanya bertujuan untuk memperkaya diri sendiri justru dilarang dalam Islam karena bisa menimbulkan penderitaan dan kesengsaraan saja bagi orang lain yang mana hal tersebut bertentangan dengan tujuan Islam hadir di muka bumi ini untuk menghadirkan kemaslahatan bagi seluruh umat.

Aspek di luar bank lainnya yang turut berakibat pada operasional pembiayaan adalah suku bunga acuan. Menurut Bank Indonesia, BI Rate merupakan suku bunga kebijakan yang menggambarkan suatu sikap atau stance kebijakan moneter yang ditetapkan oleh Bank Indonesia. BI Rate ditetapkan serta diumumkan oleh Bank Indonesia dalam setiap rapat Dewan Gubernur Bank Indonesia.

BPRS yang berada di wilayah Provinsi Jawa Timur, dilansir dari berita Dinas Kominfo Jawa Timur Tahun 2018, bahwa BPRS di Jawa Timur tahun 2018 pada triwulan pertama menunjukkan kinerja yang bagus. Kinerja yang bagus tersebut didukung dengan pertambahan aktiva, dana dari pihak ketiga dan pembiayaan yang tiap-tiap aspek bertambah sebesar $8.59 \%$, $11.37 \%$ dan 4.96\% pada tahun 2018 (Kominfo Jawa Timur, 2018) serta nilai Capital Adequacy Ratio (CAR) mencapai angka 33,86\%. Kondisi BPRS yang bagus dari segi aset dan jumlah pembiayaan yang disalurkan, namun tidak diikuti dengan perkembangan jumlah BPRS.

Provinsi Jawa Timur sendiri memiliki jumlah BPRS terbanyak di Indonesia yaitu pada tahun 2015 mencapai 29 BPRS. Jumlah tersebut berkurang dan tersisa 28 BPRS pada bulan September 2019. Jumlah BPRS berkurang dikarenakan kondisi kinerja keuangan yang tidak membaik hingga batas waktu yang telah ditentukan, membuat OJK harus mencabut izin usahanya. Rasio pembiayaan bermasalah BPRS di Jawa Timur sendiri tahun 2018 telah mencapai angka $7.21 \%$, berada diatas batas normal rasio pembiayaan bermasalah yang telah ditetapkan oleh Bank Indonesia. (Otoritas Jasa Keuangan, 2019).

Lokasi BPRS yang menjadi objek penelitiannya adalah BPRS di Provinsi Jawa Timur yang termasuk dalam area opeasional Kantor OJK Regional IV Jawa Timur. Berdasarkan data dari OJK bulan Oktober 2019, BPRS yang berada di wilayah kerja Kantor OJK Regional IV Jawa Timur tersebar di beberapa Kabupaten dan Kota di Provinsi Jawa Timur yang meliputi Kabupaten Sumenep, Sampang, Pamekasan, Sidoarjo, Gresik, Kota Surabaya, Kabupaten Lamongan, Bojonegoro, Tuban, Kota Mojokerto, Kabupaten Mojokerto dan Jombang.

Pembiayaan menjadi salah satu kegiatan pendistribusian dana yang amat banyak dilakukan oleh bank syariah dalam wujud produk pembiayaan kepada nasabah pembiayaan, maka dari itu bank wajib untuk memperhatikan berbagai faktor yang menjadi pertimbangan dalam pengambilan keputusan untuk menyalurkan pembiayaan. Periode tahun 2014-2018 pembiayaan BPRS menunjukkan perkembangan yang positif. Jumlah pembiayaan oleh BPRS yang terus meningkat tersebut, erat kaitannya dengan beberapa aspek yang turut berpengaruh. Penulis dalam penelitiain ini mengambil data yang kaitannya dengan aspek-aspek yang turut berpengaruh terhadap total pembiayaan yang dialirkan oleh BPRS, diantaranya data mengenai total keseluruhan dana untuk pembiayaan, dana dari pihak ketiga, rasio pembiayaan bermasalah, rasio likuiditas bank, rasio profitabilitas bank, data terjadinya inflasi serta suku bunga acuan. Dilandasi pula dengan beberapa hasil penelitian terdahulu yang berkaitan dengan pembiayaan memperlihatkan hasil yang beragam yaitu penelitian dari Umiyati \& Ana (2017), yang menjelaskan bahwa besar kecilnya DPK dan FDR turut berdampak terhadap pembiayaan pada Bank Umum Syariah Devisa sedangkan ROA, NPF dan inflasi tidak memiliki pengaruh. Penelitian dari Nurbiaty (2017), yang menyatakan bahwa DPK berpengaruh terhadap pembiayaan bagi hasil pada Bank Syariah Mandiri sedangkan untuk rasio NPF dan tingkat bagi hasil tidak memiliki pengaruh terhadap pembiayaan bagi hasil pada Bank Syariah Mandiri. Penelitian dari Wardiantika \& Kusumaningtias (2014), dijelaskan bahwa dana dari pihak ketiga dan rasio pembiayaan bermasalah turut berpengaruh terhadap kegiatan pembiayaan 
berbasis akad murabahah pada Bank Umum Syariah (BUS) sedangkan untuk besaran CAR dan Sertifikat Wadiah Bank Indonesia (SWBI) tidak berdampak sama sekali terhadap pembiayaan akad murabahah pada Bank Umum Syariah.

Penelitian sebelumnya yang pernah dilakukan mengenai BPR syariah beberapa diantaranya cenderung hanya fokus terhadap faktor-faktor yang mempengaruhi profitabilitas dari BPRS seperti penelitian dari Kamal (Tahun 2014) dan penelitian dari Azmy (Tahun 2018). Pembeda penelitian sebelumnya dengan penelitian ini adalah penulis memilih untuk meneliti aspek-aspek yang berpengaruh terhadap total dana yang dialokasikan pada operasional pembiayaan yang disalurkan oleh BPRS yang berlokasi Provinsi Jawa Timur untuk operasional area kerja Kantor OJK Regional IV Jawa Timur pada periode tahun 2014 triwulan pertama hingga 2018 triwulan ketiga. Variabel yang melingkupi dana pihak ketiga, rasio pembiayaan bermasalah, likuiditas bank, proftabilitas bank, angka inflasi dan besaran suku bunga acuan Bank Indonesia dipilih oleh penulis untuk dilkakukan penelitian karena berdasarkan penelitian sebelumnya menunjukkan hasil penelitian yang beragam dan tidak stabil. Objek penelitian serta periode penelitian yang dipilih oleh penulis berbeda dari penelitian sebelumnya.

\section{LANDASAN TEORI}

Pembiayaan sebagaimana yang diutarakan oleh Ismail (2011), merupakan kegiatan yang dilakukan oleh bank syariah dalam rangka penyediaan dana kepada pihak lain selain bank dengan dilakukan berdasarkan prinsip syriah. Pihak lain selain bank tersebut berasal dari masyarakat, perusahaan, intansi pemerintah atau pihak lainnya yang membutuhkan dana.

Kegiatan operasional pembiayaan yang dilakukan dengan prinsip bagi hasil rentan berpotensi terhadap risiko pembiayaan bermasalah. Risiko pembiayaan bermasalah dalam perbankan syarah erat kaitannya dengan rasio keuangan yaitu Non Performing Finance (NPF). Menurut Umam \& Utomo (2017), dalam sistem perbankan yang umum mengusung istilah kredit macet atau disebut dengan Non-Performing Loan (NPL), sedangkan pada perbankan syariah istilah tersebut disebut dengan pembiayaan bermasalah atau Non Performing Finance (NPF). Berdasar dari pengertian tersebut, NPF berpengaruh terhadap kualitas dari pembiayaan oleh bank syariah serta kinerja keuangan dari bank syariah, jika angka rasio NPF terbilang tinggi menunjukkan buruknya kualitas dari kemampuan pembiayaan serta buruknya kinerja keuangan. Menurut penelitian dari (Annisa \& Yaya, 2015), peningkatan NPF akan membuat bank syariah menambah Jumlah Penyisihan Penghapusan Aktiva Produktif (PPAP), semakin tinggi PPAP yang dianggarkan menyebabkan modal yang dimiliki bank syariah justru berkurang, hal tersebut akan mampu mengurangi kemampuan dari bank syariah dalam menyalurkan dananya dalam bentuk pembiayaan kepada masyarakat.

Perbankan syariah dalam menyalurkan pembiayaan juga perlu mempertimbangkan besaran dana yang dimilikinya atau disebut juga dengan Dana Pihak Ketiga (DPK). Dana Pihak Ketiga (DPK) menurut Antonio (2001), disebutkan bahwa DPK sebagai salah satu sumber dana untuk kegiatan operasional perbankan. Hasil penelitian dari oleh Nurbiaty (2017), menyebutkan bahwa dana yang diperoleh dari pihak ketiga berdampak positif terhadap operasional pembiayaan dengan akad bagi hasil. Peningkatan pada besaran dana dari pihak maka penyaluran pembiayaan berbasis bagi hasil juga mengalami peningkatan.

Rasio likuiditas dari bank (FDR) merupakan perbandingan antara keseluruhan dana untuk pinjaman yang telah didistribusikan oleh pihak bank dengan dana yang berhasil dikumpulkan dari masyarakat. (Dendawijaya, 2009). Menurut Widyaningrum \& Septiarini (2015), peningkatan pada rasio likuiditas memperlihatkan telah dilakukan kegiatan pembiayaan kepada masyarakat dalam jumlah yang besar, sehingga keuntungan yang didapat oleh bank turut mengalami kenaikan dengan catatan kemampuan bank syariah dalam mengalokasikan dananya untuk pembiayaan telah maksimal dilakukan. Hasil penelitian dari Umiyati \& Ana (2017), disebutkan bahwa FDR berpengaruh signifikan terhadap pembiayaan pada BUS Devisa di Indonesia, semakin tinggi FDR semakin besar pula jumlah pembiayaan yang disalurkan. 
Menurut Sudana (2009) rasio proftabilitas menggambarkan kapasitas perusahaan dalam menggunakan seluruh aset yang dimilikinya guna menghasilkan keuntungan setelah pajak. Besarnya nilai ROA yang dihasilkan, menunjukkan semakin efisien penggunaan aktiva oleh perusahaan (Sudana, 2009). Menurut penelitian dari Umiyati \& Ana (2017), jika keuntungan yang didapat oleh bank besar, manajemen bank berusaha untuk mengalokasikan keuntungannya tersebut untuk berbagai kegiatan operasional yang berpotensi menghasilkan profit tinggi bagi pihak bank itu sendiri salah satunya adalah dengan kegiatan pendistribusian pembiayaan.

Menurut Boediono (2008), memberikan definisi singkat mengenai inflasi yaitu kecenderungan dari harga-harga untuk naik secara umum dan terjadi secara berkepanjangan. Kondisi pada saat terjadinya Inflasi dapat berpengaruh pada pembiayaan karena saat terjadinya inflasi, bank sentral dalam hal ini Bank Indonesia memutuskan untuk menaikkan suku bunga. Menurut penelitian dari Saekhu (2015) upaya untuk menaikkan suku bunga acuan berakibat pada kenaikan suku bunga pada bank-bank umum serta berdampak pula pada bank syariah terutamanya pada kegiatan pembiayaan yang ikut merasakan dampak kenaikan suku bunga acuan. Pembiayaan yang disalurkan berdasarkan akad bagi hasil, dimana jika debitur mengalami kerugian pada usahanya, maka pihak debitur juga berpotensi tidak dapat mengembalikkan pembiyaan sesuai dengan kesepakatan (Saekhu, 2015).

BI Rate merupakan suku bunga acuan yang menggambarkan suatu sikap atau stance kebijakan moneter yang diambil oleh Bank Indonesia (Bank Indonesia) yang kaitannya dalam bidang moneter di Indonesia. BI Rate diumumkan dan ditetapkan oleh Dewan Gubernur Bank Indonesia. Kondisi pada saat BI Rate sedang dinaikkan, maka nilai suku bunga produk pinjaman di bank konvensional akan menjadi tinggi, hal tersebut dikarenakan bank konvensional menggunakan sistem suku bunga. Kondisi BI Rate sedang tinggi, bank cenderung menyimpan dananya di Bank Indonesia tanpa terkecuali bank syariah. Bank syariah enggan untuk mengeluarkan dananya terlebih untuk menyalurkan pembiayaan. Hal tersebut menyebabkan tingkat pembiayaan menjadi rendah.

\section{METODE PENELITIAN}

Penelitian termasuk kedalam jenis penelitian kuantitatif yang bertujuan untuk meneliti pengaruh dari dana dari pihak ketiga, rasio pembiayaan macet (NPF), rasio likuiditas bank (FDR), rasio profitabilitas (ROA), angka Inflasi yang terjadi di Indonesia dan besaran suku bunga acuan terhadap total keseluruhan dana untuk kegiatan pembiayaan yang disalurkan oleh BPRS di Provinsi Jawa Timur wilayah kerja Kantor OJK Regional IV Jawa Timur.

Jenis data yang digunakan termasuk data sekunder yaitu berupa data jumlah pembiayaan BPRS di Jawa Timur yang masuk kedalam area operasional Kantor OJK Regional IV Jawa Timur untuk periode tahun 2014 (triwulan pertama) sampai 2018 (triwulan keempat). Data untuk DPK, NPF, FDR dan ROA bersumber dari laporan keuangan triwulan BPRS yang berlokasi di Jawa Timur untuk area operasional Kantor OJK Regional 4 Jawa Timur tahun 2013.4 sampai tahun 2018.3. Data triwulan Inflasi dan BI Rate yang berlaku pada periode penelitian (2013.4 sampai 2018.3). Data sekunder diperoleh dari laporan keuangan publikasi triwulan BPRS yang diterbitkan oleh OJK melalui website resminya pada www.ojk.go.id. Data sekunder lainnya diperoleh dari laporan Bank Indonesia yaitu berupa data angka inflsi yang terjadi di Indonesia serta data suku bunga acuan Bank Indonesia yang berlaku selama kurun waktu penelitian oleh Bank Indonesia dipublikasikan pada situs resmi wmw.bigo.id.

Populasi untuk penelitian ini adalah seluruh BPR Syariah yang berlokasi di Jawa Timur serta telah terdaftar di OJK. Berdasarkan data OJK bulan Oktober 2019, jumlah seluruh BPRS yang berada di Jawa Timur tersebar diseluruh wilayah Kabupaten dan Kota ada 28 BPRS. Penelitian dilakukan pada 10 BPR Syariah di Provinsi Jawa Timur yang telah terdaftar di Otoritas Jasa Keuangan (OJK) dengan kriteria sebagai berikut: (1) BPR Syariah yang berlokasi di Provinsi Jawa Timur yang masuk kedalam wilayah kerja Kantor OJK Regional IV Jawa Timur, (2) BPR Syariah yang memberikan laporan keuangan triwulan kepada publik pada situs resmi milik OJK untuk 
periode tahun 2013 triwulan pertama sampai tahun 2018 triwulan keempat. Dipilih periode tahun tersebut dikarenakan pada tahun tersebut jumlah pembiayaan yang terus meningkat diikuti dengan jumlah peneriamaan dana dari pihak ketiga juga turut mengalami peningkatakan tetapi disisi lain angka rasio pembiayaan bersamalah justru tinggi, diatas batas normal (5\%) dan (3) memuat data lengkap laporan keuangan triwulan BPRS triwulan BPRS tahun 2013.4 sampai tahun 2018.4. Sepuluh BPRS tersebut sebagai objek penelitian yaitu BPRS Amanah Sejahtera Gresik, Mandiri Mitra Sukses Gresik, Lantabur Tebuireng Jombang, Madinah Lamongan, Unawi Barokah Sidoarjo, Annisa Mukti Sidoarjo, Bakti Makmur Indah Sidoarjo, Kota Mojokerto, Jabalnur Tebuireng Surabaya dan Sarana Prima Mandiri Pamekasan.

Setelah sampling ditentukan kemudian dilakukan pengumpulan data. Teknik untuk pengumpulan data dilakukan menggunakan teknik dokumentasi. Dokumentasi dilakukan seperti melakukan pencarian data, penggabungan, mencantumkan dan dan melakukan perhitungan terhadap bahan-bahan yang terkait dengan penelitian. Data yang dilakukan pengolahan merupakan data informasi keuangan yang disajikan selama kurun waktu triwulan BPRS yang menjadi objek penelitian dalam periode tahun 2014 triwulan pertama sampai tahun 2018 triwulan keempat.

Teknik analisis data menggunakan regresi berganda data panel dengan memanfaatkan software Eviews 9. Teknik Analisis data berupa regresi berganda data panel dilakukan dengan melakukan beberapa tahapan didalamnya yaitu tahap mengestimasi bentuk regresi untuk data panel terlebih dahulu dengan beberapa model antara lain common effect, fixed effect dan random effect. Memilih estimasi model regresi yang tepat untuk penelitian ini, terlebih dahulu dilakukan uji kesesuaian model yang meliputi uji chow dan uji hausman.

Uji Chow digunakan untuk memilih model yang tepat antara common effect atau fixed effect, jika hasil yang diperoleh nilai probabilitas chi-square kurang dari 0.05 , maka model yang terpilih common effect model dan apabila hasil yang diperoleh lebih besar dari 0.05 maka model yang terpilih adalah fixed effect model. Jika model yang terpilih fixed effect model maka perlu dilakukan uji kembali yaitu uji Hausman test. Hipotesis yang digunakan yaitu $\mathrm{H}_{0}$ : Common Effect dan $\mathrm{H}_{1}$ : Fixed Effect. Uji Hausman test digunakan untuk mengetahui model mana yang lebih tepat untuk digunakan dalam penelitian yaitu antara fixed effect model dan random effect model dengan hipotesis bahwa $\mathrm{H}_{0}$ : Random Effect dan $\mathrm{H}_{1}$ : Fixed Effect.

Uji Hipotesis dilakukan dengan melakukan uji secara individu (uji T), uji secara bersama (Uji F) dan koefisien determinasi $\left(\mathrm{R}^{2}\right)$. Uji signifikansi T dilakukan untuk mengetahui pengaruh variabel bebas terhadap variabel terikat secara individual, dimana pengujiannya diperlihatkan dengan nilai signifikansi yang dihasilkan apabila lebih kecil dari nilai (0.05) maka hipotesis penelitian diterima, dan sebaliknya jika nilai signifikansi lebih besar dari nilai $\alpha(0.05)$ maka hipotesis penelitian ditolak.

Uji F digunakan untuk mengetahui apakah variabel bebas dalam penelitian ini secara bersama-sama mempengaruhi variabel terikat. Pengujian dilakukan dengan melihat nilai signifikansi, jika nilai signifikansi yang didapatkan lebih kecil dari $\alpha(0.05)$, maka hipotesis penelitian diterima yang berarti bahwa variabel bebas secara bersama-sama mempengaruhi variabel terikat, begitu sebaliknya jika nilai yang diperoleh lebih besar dari $\alpha(0.05)$, maka hipotesis ditolak yang berarti tidak ada pengaruh secara simultan antara variabel bebas terhadap variabel terikat.

Koefisien Determinasi $\left(\mathrm{R}^{2}\right)$ bertujuan untuk mengukur seberapa besar variabel bebas mempengaruhi variabel terikat. Nilai koefisien determinasi adalah 0 dan 1 , jika nilai koefisien determinasi mendekati angka 0 memperlihatkan bahwa kemampuan variabel bebas dalam menjelaskan variabel terikat terbatas dan juga apabila mendekati nilai 1 menunjukkan bahwa variabel bebas mampu memberikan semua informasi yang dibutuhkan untuk memprediksi variabel terikat.

Satuan nilai dalam variabel berbeda, sehingga dibutuhkan suatu transformasi untuk menyamakan nilai-nilai dalam variabel, dengan demikian dapat dirumuskan model regresi berganda data panel bentuk logaritma natural dalam penelitian ini sebagai berikut:

$$
\ln Y i t=\beta_{0}+\beta_{1} \ln X_{1 \mathrm{it}-1}+\beta_{2} \mathrm{X}_{2 \mathrm{it}-1}+\beta_{3} \mathrm{X}_{3 \mathrm{it}-1}+\beta_{4} \mathrm{X}_{4 \mathrm{it}-1}+\beta_{5} \mathrm{X}_{5 \mathrm{it}-1}+\beta_{6} \mathrm{X}_{6 \mathrm{it}-1}+e i t_{-1}
$$




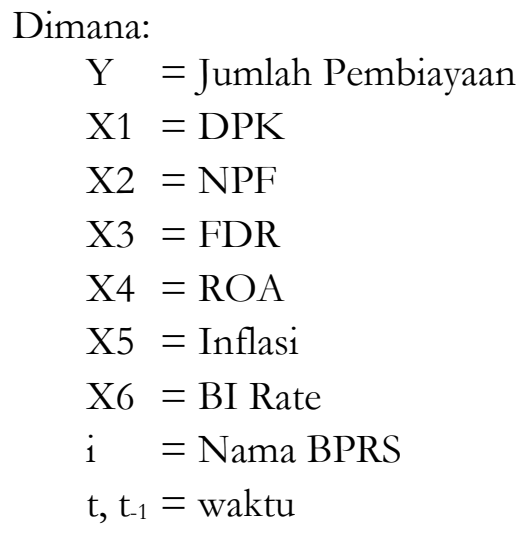

\section{HASIL DAN PEMBAHASAN}

\section{Deskripsi Data}

Statistik deskriptif digunakan untuk memperoleh karakteristik data yang menjadi objek dalam penelitian. Statistik deskriptif menunjukkan berapa nilai maksimum, nilai minimum, nilai rata-rata dan nilai standard deviasi dari data yang digunakan dalam penelitian. Berikut disajikan tabel statistik deskriptif dengan menggunakan aplikasi Eviews versi 9.0:

Tabel 1.2 Descriptive Statistic

\begin{tabular}{lccccccc}
\hline & LN_YY & LN_DPK & NPF & FDR & ROA & INFLASI & BI Rate \\
\hline Mean & 16.96396 & 16.77169 & 0.099477 & 1.240710 & 0.006364 & 0.048835 & 0.061625 \\
Median & 17.21357 & 16.79563 & 0.065200 & 1.042768 & 0.006903 & 0.039900 & 0.062500 \\
Maximum & 18.70586 & 18.65589 & 0.576400 & 3.191239 & 0.092940 & 0.083800 & 0.077500 \\
Minimum & 13.77600 & 14.18870 & 0.005300 & 0.508577 & -0.072757 & 0.028800 & 0.042500 \\
Std. Dev. & 1.275475 & 1.248684 & 0.105039 & 0.472541 & 0.025467 & 0.018920 & 0.013363 \\
Skewness & -0.822986 & -0.544557 & 2.487265 & 1.374393 & -0.596683 & 0.647010 & -0.094072 \\
Kurtosis & 2.919949 & 2.290188 & 9.899707 & 5.113953 & 4.501416 & 1.830538 & 1.202391 \\
Jarque-Bera & 22.63024 & 14.08336 & 602.9326 & 100.2052 & 30.65309 & 25.35110 & 27.22331 \\
Probability & 0.000012 & 0.000875 & 0.000000 & 0.000000 & 0.000000 & 0.000003 & 0.000001 \\
Sum & 3392.792 & 3354.338 & 19.89530 & 248.1421 & 1.272884 & 9.767000 & 12.32500 \\
Sum Sq. Dev. & 323.7404 & 310.2829 & 2.195590 & 44.43573 & 0.129067 & 0.071236 & 0.035534 \\
Observations & 200 & 200 & 200 & 200 & 200 & 200 & 200 \\
\hline
\end{tabular}

Sumber: Ouput Eviews 9 (Data Diolah Penulis)

Data untuk variabel terikat yaitu pembiayaan merupakan jumlah keseluruhan dana pembiayaan dari keseluruhan produk pembiayaan pada BPRS dengan berbagai macam akad pembiayaan yang dialokasikan oleh 10 BPR Syariah di Provinsi Jawa Timur pada wilayah kerja Kantor OJK Regional IV Jawa Timur pada periode penelitian tahun 2014 triwulan pertama sampai tahun 2018 triwulan keempat. Nilai pembiayaan selama periode tahun tersebut cenderung mengalami peningkatan.

Data untuk variabel dana dari pihak ketiga (DPK) yang digunakan merupakan data total keseluruhan dana dari pihak ketiga yang berhasil diperoleh BPR Syariah dalam periode tahun 2013 triwulan keempat sampai 2018 triwulan ketiga. Dana dari pihak ketiga yang berhasil diperoleh tersebut diperoleh BPR Syariah dengan berbagai macam akad pada produk pendanaan seperti akad wadiah, tabungan mudharabah, dan deposito mudharabah. Keseluruhan DPK yang berhasil diperoleh pada kurun waktu tersebut mengalami peningkatan.

Data untuk rasio pembiayaan bermasalah (NPF) pada BPR Syariah diperoleh dari laporan keuangan triwulan BPR Syariah yang telah mencantumkan angka rasio NPF selama kurun waktu tahun 2013 triwulan keempat sampai 2018 triwulan ketiga. NPF dari beberapa BPRS mencapai angka yang cukup tinggi, diatas 5\% (batas normal NPF) yang harus dimiliki oleh suatu bank syariah.

Data FDR yang digunakan dalam periode penelitian diperoleh dari hasil perhitungan antara total pembiayaan yang disalurkan dibagi dengan dana pihak ketiga. Berdasarkan data yang 
ada, selama tahun 2013 triwulan keempat sampai dengan tahun 2018 triwulan ketiga, FDR dari masing-masing BPRS mengalami perubahan angka yang cukup fluktuasi.

Data ROA yang digunakan merupakan hasil perhitungan dari laba sebelum pajak dibagi dengan toal aktiva yang dimiliki oleh masing-masing BPRS pada periode tahun 2013 triwulan keempat sampai 2018 triwulan ketiga. Berdasarkan data yang ada, ROA dari kesepuluh BPRS menunjukkan angka yang minus.

Data Inflasi yang digunakan dalam penelitian ini merupakan data inflasi yang terjadi pada setiap triwulanannya pada tahun 2013 triwulan keempat sampai tahun 2018 triwulan ketiga yang dipublikasikan oleh Bank Indonesia (BI) dalam laporan kebijakan moneter triwulan.

Data BI Rate untu penelitian ini merupakan data BI Rate yang berlaku pada periode penelitian yaitu rentang tahun 2014 sampai tahun 2018. BI Rate sendiri ditetapkan dan diumumkan oleh Bank Indonesia selaku lembaga independen bank sentral di Indonesia. BI Rate ditetapkan dan diumumkan setiap rapat dewan Gubernur Bank Indonesia.

\section{Hasil Uji Kesesuain Model.}

Dilakukan uji kesesuaian model terlebih dahulu sebelum melakukan analisis regresi berganda data panel. Uji kesesuaian model dilakukan untuk memilih model yang tepat pada penelitian ini. Uji kesesuaian model yang pertama adalah Uji Chow, bertujuan membandingkan estimasi model regresi yang tepat antara Common Effect Model atau Fixed Effect Model yang terpilih.

Tabel 1.3 Hasil Tes Uji Chow

\begin{tabular}{lccc}
\multicolumn{1}{c}{ Effects Test } & Statistic & d.f. & Probabilitas \\
\hline $\begin{array}{l}\text { cross section F } \\
\text { cross section } \\
\text { chi-square }\end{array}$ & 4.794524 & $-10,183$ & 0.0000 \\
\multicolumn{1}{c}{ Sumber: Output Eviews 9 (Data Diolah Penulis) }
\end{tabular}

Sumber: Output Eviews 9 (Data Diolah Penulis)

Berdasarkan hasil tes uji chow diperoleh angka probabilitas pada cross-section chi-square yaitu 0.000 yang artinya kurang dari $(<0.05)$, jadi terpilih estimasi model Fixed Effect Model. Terpilihnya estimasi model Fixed Effect Model, maka dilakukan kembali uji model yaitu hausman test. Hausman test berfungsi memilih model yang lebih tepat, apakah Fixed Effect Model atau Random Effet Model yang terpilih. Berikut hasil uji hausman test:

Tabel 1.4 Hasil Hausman Test

\begin{tabular}{lccc}
\hline Test Summary & $\begin{array}{c}\text { Chi-Sq. } \\
\text { Statistic }\end{array}$ & $\begin{array}{c}\text { Chi-Sq. } \\
\text { d.f. }\end{array}$ & Probabilitas \\
\hline $\begin{array}{l}\text { Cross-section } \\
\text { random }\end{array}$ & 21.480179 & 6 & 0.0015 \\
\hline \multicolumn{2}{l}{ Sumber: Hasil Output Eviews Versi 9 (Data Diolah Penulis) }
\end{tabular}

Hasil dari dilakukannya uji hausman test diperoleh nilai dari cross section random sebesar 0.0015 yang artinya lebih kecil dari $(<0.05)$, maka estimasi model yang terpilih yaitu Fixed Effect Model dan dapat diduga bahwa keenam variabel secara bersama-sama memiliki pengaruh terhadap jumlah keseluruhdan dana untuk pembiayaan yang didistribusikan oleh BPR Syariah. 


\section{Hasil Analisis Regresi Data Panel}

Hasil dari dua kali uji kesesuaian model, diperoleh model yang tepat untuk penelitian ini adalah Fixed Effect Model. Berikut hasil persamaan:

Tabel 1.5 Hasil Regresi Berganda

\begin{tabular}{ccccc}
\hline Variable & Coefficient & Std. Error & t-Statistic & Probabilitas \\
\hline C & -0.021927 & 0.755791 & -0.029013 & 0.9769 \\
LN_DPK & 0.977995 & 0.041622 & 23.49731 & 0.0000 \\
NPF & -0.312035 & 0.158032 & -1.974506 & 0.0498 \\
FDR & 0.47471 & 0.045316 & 10.47564 & 0.0000 \\
ROA & 0.223581 & 0.593402 & 0.376779 & 0.7068 \\
INFLASI & 0.069755 & 0.771733 & 0.090387 & 0.9281 \\
BI RATE & 0.332504 & 1.181294 & 0.281474 & 0.7787
\end{tabular}

Sumber: Hasil Output Eviews (Data Diolah Penulis)

Berdasarkan estimasi model yang terpilih yaitu Fixed Effect Model maka dapat dirumuskan model persamaan dalam penelitian ini:

\section{LnPembiayaan $=-0.021927+0.977995 \ln \mathrm{DPK}-0.312035 \mathrm{NPF}+0.47471 \mathrm{FDR}+$ 0.223581ROA + 0.069754575Inflasi + 0.332504BI Rate}

\section{Uji Hipotesis}

\section{a. Uji T (individu)}

Angka probabilitas pada variabel DPK yaitu 0.0000 lebih kecil dibandingkan dengan nilai signifikansi 0.05 maka hipotesis diterima. Hal tersebut menunjukkan DPK mempunyai dampak yang positif dan berarti terhadap total dana untuk pembiayaan yang disalurkan oleh BPRS di Provinsi Jawa Timur untuk wilayah kerja Kantor OJK Regional IV Jawa Timur.

Nilai t-Statistic variabel NPF sebesar -1.974506 dengan probablilitas 0.0498, artinya kurang dari 0.05 maka hipotesis penelitian diterima, hasil tersebut menunjukkan NPF memiliki dampak yang negatif terhadap total keseluruhan pembiayaan yang didistribusikan oleh BPRS Provinsi Jawa Timur yang masuk wilayah kerja Kantor Regional IV Jawa Timur.

Nilai signifikansi t pada FDR yaitu 0.0000 kurang dari 0.05 maka hipotesis diterima, yang artinya bahwa variabel FDR secara individu mempunyai pengaruh pada total keseluruhan dana untuk operasional pembiayaan oleh BPRS Provinsi Jawa Timur untuk area kerja Kantor OJK Regional IV Jawa Timur.

Nilai signifikasi t pada ROA sebesar 0.7068 lebih besar dari nilai signifikansi 0.05 maka hipotesis ditolak, sehingga memperlihatkan ROA tidak berpengaruh pada jumlah dana untuk kegiatan pembiayaan oleh BPR Syariah di Provinsi Jawa Timur yang masuk area operasional Kantor OJK Regional IV Jawa Timur.

Nilai signifikansi t untuk variabel Inflasi yakni 0.9281 yaitu lebih besar dari 0.05 maka hipotesis ditolak, menunjukkan bahwa angka inflasi yang terjadi secara individu tidak berakibat sama sekali terhadap jumlah dana untuk pembiayaan oleh BPR Syariah di Jawa Timur untuk wilayah kerja Kantor OJK Regional IV Jawa Timur.

Nilai signifikansi t dari variabel BI Rate dari hasil olah data yaitu 0.7787 lebih besar dari 0.05, maka hipotesis ditolak. Hal tersebut menggambarkan besaran suku bunga acuan tidak memiliki pengaruh terhadap jumlah pembiayaan yang disalurkan oleh BPRS yang berlokasi di Jawa Timur pada area kerja Intansi OJK Regional IV Jawa Timur. 


\section{b. Uji F}

Uji F dalam penelitian ini bertujuan untuk mengetahui apakah variabel bebas $(\mathrm{X})$ secara bersama-sama mempengaruhi variabel terikat $(\mathrm{Y})$.

Tabel 1.6 Hasil Uji Statistik F (Simultan)

\begin{tabular}{cc}
\hline F-statistic & Prob(F-statistic) \\
\hline 1304.315 & 0.000000 \\
\hline
\end{tabular}

\section{Sumber: Hasil Output Eviews (Data Diolah Penulis)}

Berdasarkan tabel diatas, angka F-statistic sebesar 1304.315 dengan probabilitas (F-statistic) yaitu 0.000000 membuktikan bahwa angka tersebut kurang dari dari nilai signifikansi $\mathrm{f}$ sebesar $(a=0.05)$ maka hipotesis diterima. Hasil tersebut memperlihatkan bahwa dana dari pihak ketiga (DPK), rasio pembiayaan bermasalah (NPF), rasio likuiditas bank (FDR), rasio profitabilitas (ROA), angka Inflasi yang terjadi di Indonesia dan penetapan suku bunga acuan secara bersama-sama mempengaruhi jumlah kseluruhan dana pembiayaan yang dikeluarkan oleh BPRS di Provinsi Jawa Timur yang masuk wilayah kerja Kantor OJK Regional IV Jawa Timur.

\section{c. Uji Koeifisien Determinasi $\left(\mathbf{R}^{2}\right)$}

Uji koefisien Determinasi $\left(\mathrm{R}^{2}\right)$ pada penelitian ini guna menimbang seberapa besar kemampuan model dalam menjelaskan variasi dari variabel dependent. Berikut dipaparkan hasil koefisien determinasi pada penelitian ini:

\begin{tabular}{cc} 
Tabel 1.7 Hasil Keofisien Determinasi \\
\hline R-squared & Adjusted R-squared \\
\hline 0.991307 & 0.990547 \\
\hline
\end{tabular}

\section{Sumber: Hasil Output Eviews (Data Diolah Penulis)}

Berdasarkan tabel 1.7, diperoleh angka adjusted-squared yaitu 0.990547 (99.05\%). Angka tersebut menggambarkan bahwa untuk dana dari pihak ketiga, rasio pembiayaan macet, rasio likuiditas bank, rasio profitabilitas bank, angka inflasi dan besaran BI Rate berdampak sebesar $99.05 \%$ atas jumlah keseluruhan dana untuk kegiatan pembiayaan yang disalurkan oleh BPRS sedangkan sisanya yaitu sebesar $0.95 \%$ dipengaruhi oleh variabel lain yang tidak digunakan dalam penelitian ini.

\section{Pengaruh Dana Dari Pihak Ketiga (DPK) Terhadap Jumlah Dana Keseluruhan Untuk Pembiayaan Yang Disalurkan Oleh BPR Syariah Di Provinsi Jawa Timur Untuk Area Kerja Kantor OJK Regional IV Jawa Timur}

DPK secara parsial atau individu berpengaruh positif terhadap total dana untuk pembiayaan yang disalurkan oleh BPRS pada Provinsi Jawa Timur untuk wilayah kerja Kantor OJK Regional IV Jawa Timur. Hasil tersebut sejalan dengan teori yang dikatakan oleh (Antonio, 2001), bahwa DPK merupakan salah satu sumber dana operasional utama bagi perbankan syariah, sehingga DPK berpengaruh terhadap salah satu kegiatan operasional perbankan syariah yaitu dalam bentuk menyalurkan pembiayaan kepada masyarakat.

Hasil dari pengkajian mewakili fakta yang terjadi di lapangan. Terjadi peningkatan pembiayaan pada BPR Syariah yang berada pada wilayah Provinsi Jawa Timur untuk area operasional Kantor OJK Regional IV Jawa Timur. Berdasarkan data yang diperoleh, terjadi peningkatan dana dari pihak ketiga yang berhasil dihimpun oleh BPR Syariah dalam kurun waktu tahun (2014-2018), dari peningkatan DPK tersebut menyebabkan peningkatan terhadap pembiayaan yang disalurkan selama periode penelitian (2014-2018). Hal tersebut menunjukkan bahwa antara jumlah pembiayaan yang disalurkan dengan DPK berkaitan satu sama lain, jika terdapat peningkatan penerimaan dana dari pihak ketiga, bank cenderung akan mengalokasikan dana untuk pembiayaan dalam jumlah yang besar pula. Hal tersebut tidak terlepas dari tujuan bank 
untuk memperoleh profit secara maksimal dari kegiatan penyaluran pembiayaan, semakin besar pembiayaan yang didistribusikan maka semakin besar pula keuntungan yang bisa didapatkan.

Hasil demikian juga searah dengan penelitian dari Bakti (2018) serta hasil observasi dari Nurbiaty (2017) yang menyebutkan bahwa terdapat pengaruh yang berarti antara dana yang berhasil didapatkan dari pihak ketiga terhadap penyaluran pembiayaan berbasis bagi hasil pada perbankan syariah.

Bagian dari bank syariah yaitu BPR Syariah juga melakukan penghimpunan dana pihak ketiga (DPK) dari masyarakat, yang mana dana tersebut merupakan amanat. BPRS berkewajiban untuk menjaga amanat tersebut dengan baik, sebagaimana yang telah diterangkan dalam Al-qur'an, bahwa dalam menjaga sebuah amanat jangan pernah mencoba untuk mengkhianati amanat tersebut. Dijelaskan dalam Al-Qur'an surah AL-Anfal 27:8

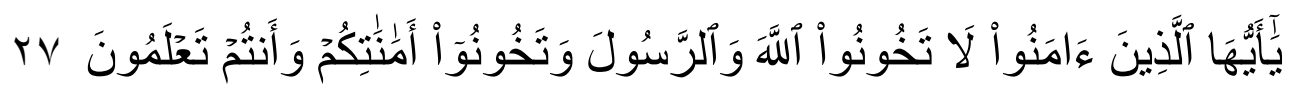

Artinya: "Hai orang-orang yang beriman, janganlah kamu mengkbianati Allah dan Rasul (Muhammad) dan (juga) janganlah kamu mengkhianati amanat-amanat yang dipercayakan kepadamu, sedang kamu mengetahui".

Ayat tersebut menjelaskan sebuah konsep bahwa segala sesuatu hal baik yang berwujud harta, benda, pesan atau lainnya yang diamanatkan kepada seseorang maupun lembaga, tanpa terkecuali DPK merupakan sebuah modal yang dititipkan pemiliknya kepada bank syariah untuk dapat dikelola secara baik. Pihak bank syariah tidak diperbolehkan sedikitpun berkhianat terhadap dana yang telah dititipkan tersebut. BPRS dipercaya oleh masyarakat sebagai tempat untuk menitipkan dananya dengan tujuan dana tersebut dapat dijaga dan dikelola dengan baik serta berharap ada keuntungan yang bisa pihak bank syariah berikan atas dana yang dikelola tersebut sesuai dengan kesepatan antara keduanya. Pihak bank syariah berkewajiban mengelola dana tersebut dengan segala bentuk prosedur dan kebijakan yang telah tertera pada operasional bank syariah.

\section{Pengaruh Rasio Pembiayaan Bermasalah (NPF) Atas Total Dana Untuk Kegiatan Pembiayaan Yang Didistribusikan Oleh BPR Syariah Di Provinsi Jawa Timur Yang Masuk Wilayah Kerja Kantor OJK Regional IV Jawa Timur}

Rasio pembiayaan bermasalah memiliki akibat yang negatif dan berarti atas total keseluruh dana yang didistribusikan BPR Syariah untuk kegiatan pembiayaan pada BPRS Provinsi Jawa Timur yang masuk wilayah kerja Kantor Regional IV Jawa Timur. Hasil tersebut sejalan dengan yang disampaikan oleh Umam \& Utomo (2017), NPF berawal dari sebuah "wanprestasi" oleh nasabah pembiayaan yang tidak dapat memenuhi janjinya untuk mengembalikan dana pembiayaan sesuai dengan perjanjian.

Berdasar pada "wanprestasi" tersebut berpengaruh terhadap kinerja pembiayaan oleh bank syariah yang berakibat terjadinya pembiayaan bermasalah, semakin banyak pembiayaan yang macet maka bank syariah lebih waspada dalam mengeluarkan pembiayaan kepada nasabah pembiayaan. Kehati-hatian bank syariah tersebut membuat jumlah pembiayaan yang disalurkan ke masyarakat menjadi berkurang, mengingat bank tidak ingin mengambil risiko di tengah jumlah pembiayaan bermasalah yang besar. Besarnya pembiayaan bermasalah membuat BPRS akan meningkatkan nilai Penyisihan Penghapusan Aktiva Produktif (PPAP) yang wajib dibuat oleh pihak BPRS sebagaimana yang tertera pada peraturan Bank Indonesia. Peningkatan jumlah untuk PPAP secara terus menerus berpengaruh terhadap tingkat likuiditas bank, aset pada bank syariah akan semakin berkurang. Aset pada bank syariah yang berkurang mampu mempengaruhi kemampuan bank dalam mendistribusikan pembiayaan.

Islam sendiri telah mengajarkan bahwa siapapun yang memiliki janji berkewajiban untuk menepati janji tepat pada waktunya. Pembiayaan bermasalah yang terjadi pada transaksi pembiayaan di bank syariah, menunjukkan bahwa nasabah pembiayaan tidak dapat menetapi janjinya untuk mengembalikan dana yang telah dipinjamnya tepat pada waktunya sesuai dengan perjanjian. Seperti dijelaskan dalam Qur'an Surat An-Nahl ayat 91: 


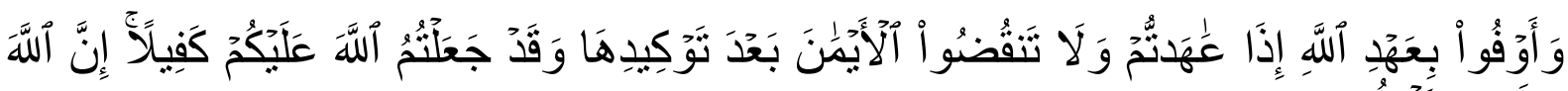

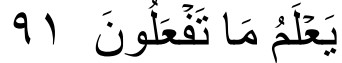 \\ Artinya: "Dan tepatilah perjanjian dengan Allah apabila kamu berjanji dan janganlah kamu membatalkan sumpah-sumpah (mu) itu, sesudah menegubkannya, sedang kamu telah menjadikan Allah sebagai saksimu (terhadap sumpah-sumpahmu itu). Sesunggubnya Allab mengetahui apa yang kamu perbuat".}

Hasil dari pengkajian ini sesuai dengan penelitian yang dilakukan (Ovami \& Thohari, 2018) dan L. N. Annisa \& Yaya (2015) bahwa rasio pembiayaan bermasalah berdampak negatif terhadap kegiatan pendistribusian pembiayaan, tingginya angka rasio pembiayaan bermasalah (NPF), akan dapat mengurangi jumlah keseluruhan dana untuk pembiayaan yang akan disalurkan.

\section{Pengaruh Rasio Likuiditas (FDR) Atas Total Kseluruhan Dana Untuk Kegiatan Pembiayaan Oleh BPR Syariah Di Provinsi Jawa Timur Yang Masuk Wilayah Kerja Kantor OJK Regional IV Jawa Timur}

FDR berpengaruh positif signifikan terhadap pembiayaan oleh BPRS. Hasil demikian konsisten dengan hasil penelitian dari Umiyati \& Ana (2017) dan Destiana (2016) bahwa rasio likuiditas (FDR) memiliki dampak positif atas kegiatan pembiayaan di industri perbankan syariah. Menurut Husaeni (2017) menyebutkan bahwa jika semakin tinggi FDR menunjukkan semakin rendah kemampuan likuiditas bank, karena pada prinsipnya angka FDR yang tinggi menunjukkan semakin riskan kondisi likuiditas pada bank.

Teori tersebut tidak berlaku pada BPRS yang berada di Provinsi Jawa Timur untuk wilayah kerja Kantor OJK Regional IV Jawa Timur. Berdasarkan data dari laporan keuangan triwulan BPRS tersebut, pembiayaan yang disalurkan justru menunjukkan kenaikan angka selama periode penelitian (2014.1 sampai 2018.4), kendati rasio FDR menunjukkan angka yang tinggi. Fakta tersebut didukung dengan hasil penelitian dari Umiyati \& Ana (2017) bahwa rasio likuiditas difungsikan menjadi parameter guna memantau kapasibilitas bank dalam fungsinya menjadi lembaga intermediate (perantara) sektor keuangan, sehingga besarnya rasio likuiditas yang dimiliki memperlihatkan bagusnya kemampuan bank dalam menjalankan fungsinya dengan demikian besaran dana untuk pembiayaan yang disalurkan oleh bank bertambah.

BPRS menggunakan DPK yang digunakan untuk kegiatan pembiayaan sebagai sumber likuiditasnya. Hal tersebut menunjukkan bahwa pembiayaan oleh BPRS perlu dilakukan untuk menjaga likuiditas BPRS itu sendiri serta menunjukkan pula bahwa BPRS pada faktanya telah menjalankan amanatnya dengan baik sebagai wujud BPRS telah mengelola dana dari masyarakat sesuai dengan prosedur yang ada salah satunya yaitu dengan kegiatan operasional penyaluran pembiayaan.

\section{Pengaruh ROA Atas Besaran Dana Untuk Pembiayaan Oleh BPR Syariah di Provinsi Jawa Timur Masuk Wilayah Kerja Kantor OJK Regional IV Jawa Timur}

Besaran nilai ROA yang diperoleh tidak berdampak terhadap besaran dana untuk pembiayaan yang dikeluarkan oleh BPRS di Provinsi Jawa Timur untuk area operasional Kantor OJK Regional IV Jawa Timur. Berdasarkan dari hasil pengkajian diperkuat juga dengan penelitian yang dilakukan oleh Widiastuty (2017) dijelaskan bahwa rasio untuk profitabilitas yang diperoleh oleh bank sama sekali tidak memiliki dampak terhadap kapasitas pembiayaan dengan akad bagi hasil. Penelitian lain juga menyatakan hal yang sama, seperti penelitian dari Umiyati \& Ana (2017) menyebutkan rasio profitabilitas tidak mempengaruhi kegiatan pembiayaan yang dilakukan oleh Bank Umum Syariah (BUS) Devisa. Menurut Umiyati \& Ana (2017), alasan kenapa rasio profitabilitas tidak mempengaruhi kegiatan pembiayaan yang dilakukan oleh BUS Devisa dikarenakan tidak stabilnya antara peningkatan maupun penurunan besaran profit yang diperoleh BUS Devisa di setiap triwulan pada kurun waktu penelitian.

Hasil dari penelitian ini juga mewakili fakta yang terjadi di lapangan. Berdasarkan data dari laporan keuangan triwulan BPRS, angka ROA pada BPRS menunjukkan kenaikan dan penurunan 
dalam setiap triwulannya. Beberapa BPR Syariah yang berada di Provinsi Jawa Timur untuk area operasional OJK Regional IV Jawa Timur selama kurun waktu penelitian, diketahui nilai ROA yang dimiliki rendah bahkan ada yang negatif. Angka ROA yang negatif tersebut, tidak membuat pembiayaan yang disalurkan menurun, justru terdapat penambahan nominal pembiayaan yang disalurkan dalam periode triwulannya. Fakta tersebut memperlihatkan profitabilitas yang diperoleh BPRS tidak memberikan efek yang berarti terhadap besaran pendistribusian dana untuk pembiayaan oleh BPRS kepada masyarakat. Operasional pembiayaan pada BPR Syariah akan tetap berjalan kendati nilai profitabilitas yang dihasilkan oleh bank tersebut tidak dalam kondisi bagus bahkan minus. Operasional pembiayaan oleh BPR Syariah sangat bergantung pada penerimaan sumber dana bank dari pihak ketiga, semakin besar dana dari pihak ketiga yang diperoleh semakin besar pula dana yang dialokasikan untuk operasional pembiayaan oleh BPR Syariah.

Profitabilitas dapat diperoleh apabila bank syariah dalam kegiatan operasional salah satunya telah menerapkan prinsip dalam bekerja sejalan dengan prinsip berbisnis yang baik menurut Islam. Prinsip berkerja yang dibenarkan menurut Islam tersebut diantaranya dengan memiliki karakter amanat dan tabligh (menyampaikan) dalam bekerja. Menjalankan amanat dalam mengelola dana dari masyarakat serta menyampaikan informasi perbankan yang diperlukan oleh nasabah. Pihak bank memerlukan kepercayaan dari nasabah maupun investor melalui informasi tersebut untuk dapat menunjang profitabilitas bank itu sendiri.

\section{Pengaruh Inflasi Atas Total Keseluruhan Besaran Dana Untuk Pembiayaan Yang Dikeluarkan Oleh BPRS di Provinsi Jawa Timur Masuk Wilayah Kerja Kantor OJK Regional IV Jawa Timur}

Berlangsungnya Inflasi di Indonesia, tidak berdampak terhadap besaran dana untuk kegiatan pembiayaan oleh BPRS. Hasil tersebut sejalan dengan hasil penelitian dari Wahiddudin (2018), dijelaskan terjadinya inflasi di Indonesia sama sekali tidak memberikan dampak terhadap pembiayaan untuk UMKM dan juga hasil obeservasi dari Umiyati \& Ana (2017) menjelaskan bahwa inflasi tidak memiliki pengaruh terhadap pembiayaan yang dilakukan oleh Bank Umum Syariah Devisa. Menurut Widiastuty (2017), selama inflasi yang terjadi masih dalam batasan kondisi yang aman bagi perbankan syariah, terjadinya inflasi tidak akan berdampak sama sekali terhadap kegiatan bank syariah salah satunya kegiatan pembiayaan. Pembiayaan pada BPR Syariah tetap terus berjalan sebagaimana mestinya kendati inflasi sedang terjadi, mengingat inflasi tidak memberikan dampak sama sekali terhadap kegiatan perbankan syariah terutama dalam operasional pembiayaan. Berlangsungnya inflasi di Indonesia membuat Bank Indonesia akan menurunkan tingkat suku bunga acuan yang dapat pula berdampak pada suku bunga bank, mengingat pembiayaan pada bank syariah tidak menggunakan sistem bunga bank maka ketika ada perubahan tingkat suku bunga bank pada tingkat berapapun tidak mempengaruhi kegiatan pembiayaan. Tingkat pengembalian pembiayaan diberikan nasabah kepada pihak bank berdasarkan nisbah bagi hasil sesuai kesepakatan keduanya.

Pakar ekonomi Islam dalam Awaludin (2017) memandang bahwa terjadinya inflasi dapat menimbulkan akibat buruk bagi perekonomian. Salah satunya yaitu terjadinya inflasi kian mendorong masyarakat untuk berinvestasi pada benda-benda yang tidak produktif namun memiliki nilai yang tinggi dengan terus menambah kekayaan pada emas, mata uang asing dan lainnya. Penumpukan harta tersebut menunjukkan masyarakat cenderung egois yang hanya memikirkan dirinya sendiri dengan terus memperkaya diri, dampaknya adalah harta seseorang tersebut tidak terdistribusikan sebagaimana semestinya. Masyarakat cenderung enggan untuk berzakat, infaq maupun shadaqah pada kondisi inflasi yang terjadi.

\section{Pengaruh BI Rate Terhadap Jumlah Pembiayaan Yang Disalurkan Oleh BPRS di Provinsi Jawa Timur Masuk Wilayah Kerja Kantor OJK Regional IV Jawa Timur}

Suku bunga acuan (BI Rate) yang ditetapkan oleh bank Indonesia dalam setiap rapat dewan Gubernur Bank Indonesia pada faktanya tidak menimbulkan dampak yang berarti terhadap besaran dana untuk kegiatan pembiayaan oleh BPRS di Provinsi Jawa Timur yang masuk wilayah kerja Kantor OJK Regional IV Jawa Timur. Hasil tersebut sama dengan penelitian oleh (Wahiddudin, 
2018), bahwa variabel BI Rate tidak memiliki pengaruh terhadap pembiayaan baik pembiayaan UMKM, dikarenakan transaksi pembiayaan pada industri perbankan berbasis syariah tidak menetapkan suku bunga acuan sebagai rujukan untuk operasional pembiayaan, yang mana hal tersebut memungkinkan nasabah lebih memilih pembiayaan dengan tingkat pengembalian yang lebih rendah dibandingkan kredit pada perbankan yang umum. Tingkat pengembalian rendah lebih dipilih untuk dijadikan sebagai acuan pembiayaan perbankan syariah, karena jika terjadi kenaikan maupun penurunan BI Rate sama sekali tidak menimbulkan dampak pada kegiatan operasional pembiayaan oleh bank syariah.

Kesimpulan berbeda diperoleh dari observasi yang dilakukan oleh Ma'arifa \& Budiyono (2015) yang menyebutkan BI Rate berpengaruh terhadap pembiayaan. Menurut keduanya dalam penentuan margin pembiayaan yang menggunakan BI Rate yang berlaku, sehingga BI Rate berdampak negatif pada kegiatan pembiayaan bank syariah maka ketika suka bunga acuan yang ditetapkan naik, besaran pembiayaan yang akan dikeluarkan justru berkurang.

Berdasarkan hasil uji parsial dalam penelitian ini penyebab BI Rate tidak berpengaruh terhadap pembiayaan bank syariah dikarenakan ketika terjadinya perubahan suku bunga acuan, tidak menyebabkan penurunan maupun peningkatan jumlah pembiayaan yang disalurkan oleh BPRS di Provinsi Jawa Timur yang masuk wilayah kerja Kantor OJK Regional IV Jawa Timur. BPRS tersebut kemungkinan tidak menggunakan BI Rate sebagai acuan dalam menentukan besaran pembiayaan. Pihak BPRS menggunakan acuan nisbah bagi hasil berdasar kesepatan antara pihak bank syariah dengan nasabah pendanaan dalam menentukan besaran pembiayaan. Tingkat bagi hasil yang cukup besar bank akan memperoleh laba yang tinggi dari operasional pembiayaan tersebut, bank akan menambah besaran dana yang dialokasikan untuk kegiatan pembiayaan dan sebaliknya jika nisbah bagi hasil rendah, dana untuk pembiayaan yang disalurkan jumlahnya berkurang. Jumlah pembiayaan yang disalurkan oleh BPRS selain berpegang pada tingkat bagi hasil, juga bergantung pada besaran DPK yang berhasil dihimpun, serta hasil dari portofolio yang berhasil dikelola dengan baik oleh manajemen BPRS.

Islam sendiri telah mengharamkan suku bunga bank dan termasuk dalam kategori riba. Islam lebih merekomendasikan adanya nisbah bagi hasil dalam pembagian keuntungan antara nasabah dengan pihak bank syariah. Penentuan nisbah bagi hasil yang tidak menggunakan BI Rate sebagai acuannya dalam operasional BPRS, sudah menjadi langkah yang tepat dalam menjalankan ekonomi yang sesuai dengan syariah Islam dalam kehidupan.

\section{Pengaruh Dana Dari Pihak Ketiga, Rasio Pembiayaan Bermasalah (NPF), FDR, ROA, Inflasi dan BI Rate Terhadap Jumlah Pembiayaan Yang Disalurkan Oleh BPRS di Provinsi Jawa Timur Yang Masuk Wilayah Kerja Kantor OJK Regional IV Jawa Timur.}

Hasil dari uji F, memperlihatkan bahwa besaran dana dari pihak ketiga, rasio pembiayaan bermasalah, likuiditas bank, ROA, angka inflasi di Indonesia dan besaran suku bunga acuan memiliki pengaruh secara bersama-sama terhadap total besaran dana untuk operasional pembiayaan yang dikeluarkan oleh BPRS di Provinsi Jawa Timur pada wilayah kerja Kantor OJK Regional IV Jawa Timur. Keenam variabel secara bersamaan menimbulkan efek yang berarti pada total dana pendanaan BPRS, dikarenakan tiga variabel seperti DPK, NPF dan FDR memiliki pengaruh secara parsial terhadap jumlah pembiayaan yang disalurkan oleh BPRS di Provinsi Jawa Timur yang masuk wilayah kerja Kantor OJK Regional IV Jawa Timur sedangkan tiga lainnya seperti ROA, Inflasi dan BI Rate tidak memiliki pengaruh secara parsial.

Dijelaskan hasil dari observasi ini sama dengan penelitian yang dilakukan oleh (Umiyati \& Ana, 2017), disebutkan variabel dana yang dihimpun dari pihak ketiga, rasio likuiditas bank, rasio profitabilitas, pembiayaan bermsalah dan terjadinya Inflasi keseluruhannya berdampak pada kegiatan operasional pembiayaan pada Bank Umum Syariah Devisa di Indonesia.

Total dana yang dialokasikan untuk kegiatan pembiayaan oleh BPR Syariah dipengaruhi oleh dana dari pihak ketiga, tingkat pembiayaan bermasalah serta tingkat likuiditas bank syariah. Operasional bank syariah yang bergantung pada besaran dana yang berhasil dihimpun oleh bank, semakin besar dana dari pihak ketiga yang berhasil dihimpun bank cenderung menyalurkannya untuk pembiayaan dalam jumlah besar. Hal tersebut tidak terlepas dari tujuan bank syariah untuk 
memperoleh keuntungan, sehingga dana dari pihak ketiga tersebut dikelola semaksimal mungkin. Kurun waktu tahun 2014 sampai 2018, pendistribusian dana untuk pembiayaan oleh BPR Syariah di Provinsi Jawa Timur untuk wilayah kerja Kantor OJK Regional IV Jawa Timur terus meningkat, peningkatan tersebut diikuti dengan peningkatan penerimaan dana dari pihak ketiga.

Pembiayaan oleh bank syariah tidak terlepas dari risiko pembiayaan bermasalah. Besarnya tingkat pembiayaan bermasalah memungkinkan bank untuk lebih berhati-hati dalam menyalurkan pembiayaan, hal tersebut berdampak pada besaran dana yang dikeluarkan oleh bank syariah menjadi berkurang. Pembiayaan bermasalah yang tinggi juga mendorong bank syariah lebih meningkatkan penggunaan dana untuk alokasi Penghapusan Pada Aktiva Produktif (PPAP) sehingga modal yang dimiliki bank syariah berkurang yang berdampak pada dana untuk operasional pembiayaan menjadi berkurang. Rasio pembiayaan bermasalah (NPF) pada BPR Syariah di Jawa Timur untuk wilayah kerja Kantor OJK Regional IV Jawa Timur dalam kurun waktu tahun 2014-2018 yang tinggi tidak membuat pembiayaan berkurang justru terus mengalami peningkatan. Pembiayaan oleh BPRS yang terus meningkat tersebut dikarenakan pihak BPR Syariah telah memaksimalkan penerimaan dana dari pihak ketiga untuk operasional pembiayaan.

Besaran dana untuk pembiayaan oleh BPR Syariah juga dipengaruhi oleh tingkat likuiditas bank syariah (FDR). FDR digunakan oleh bank syariah sebagai indikator untuk melihat kemampuan bank dalam menyalurkan pembiayaan kepada nasabah, semakin tinggi angka FDR bank syariah, menunjukkan semakin besar pula kemampuan bank dalam mendistribusikan dana untuk pembiayaan. Fakta yang terjadi bahwa pembiayaan oleh BPR Syariah di Provinsi Jawa Timur pada area kerja Kantor OJK Regional IV Jawa Timur masih mengalami peningkatan, kendati nilai FDR mengalami perubahan yang tidak konsisten. Hal tersebut menunjukkan bahwa kemampuan bank dalam menyalurkan pembiayaan kepada nasabah masih tetap baik.

Tingkat profitabilitas yang diperoleh oleh BPR Syariah untuk wilayah kerja Kantor OJK Regional IV Jawa Timur tidak berpengaruh terhadap pembiayaan oleh BPR Syariah mengingat tidak konsistennya nilai profitabilitas yang diperoleh. Nilai profitabilitas yang diperoleh cenderung mengalami kenaikan dan penurunan selama periode tahun 2014-2018, sehingga tidak bisa dijadikan sebagai indikator BPR Syariah dalam menyalurkan pembiayaan kepada nasabah. BPR Syariah tetap menyalurkan pembiayaan kepada nasabah kendati nilai profitabilitas yang diperoleh bank syariah tidak besar, bahkan mengalami rugi dilihat dari nilai ROA yang minus.

Besaran dana untuk pembiayaan sama sekali tidak berpatokan pada tingkat inflasi dan tingkat suku bunga acuan yang ditetapkan oleh Bank Indonesia. Berapapun tingkat inflasi yang terjadi di Indonesia serta tingkat suku bunga acuan tidak berpengaruh terhadap besaran dana untuk kegiatan pembiayan oleh BPR Syariah, mengingat bank syariah pada operasional pembiayaannya menggunakan prinsip bagi hasil.

BPR Syariah di Provinsi Jawa Timur untuk wilayah kerja Kantor OJK Regional IV Jawa Timur tetap menyalurkan pembiayaan kepada nasabah dalam kurun waktu tahun 2014-2018, kendati nilai ROA Profitabilitas yang mereka peroleh kecil bahkan angka ROA ada yang memperlihatkan nilai negatif. Kondisi Inflasi yang terjadi dan penetapan suku bunga acuan oleh Bank Indonesia di angka berapapun tidak membuat operasional pembiayaan oleh BPR Syariah berhenti, mengingat operasional pembiayaan BPR Syariah bergantung pada besaran penerimaan dana dari pihak ketiga serta tidak digunakannya sistem bunga bank pada operasional pembiayaan. Angka rasio pembiayaan bermasalah yang tinggi juga tidak menghambat operaional pembiayaan BPR Syariah, dikarenakan BPR Syariah memiliki kemampuan yang baik dalam menjaga rasio likuiditas internal perusahaannya dengan nilai FDR memperlihatkan angka cukup tinggi pada beberapa BPR Syariah untuk wilayah kerja kantor OJK Regional IV Jawa Timur sehingga tetap bisa menyalurkan pembiayaan kepada nasabah. Hal tersebut juga telah menggambarkan BPR Syariah telah berhasil menjalankan perannya sebagai lembaga perantara di sektor perbankan yaitu dengan menyalurkan pembiayaan kepada nasabah. 


\section{PENUTUP}

Berpatokan dari hasil observasi serta pembahasan dapat ditarik sebuah kesimpulan bahwa:

1. Dana dari pihak ketiga, rasio pembiayaan bersamalah dan rasio likuiditas bank secara parsial (individu) memiliki pengaruh secara signifikan sedangkan Return On Asset (ROA), terjadinya Inflasi dan BI Rate yang belaku pada kurun waktu tersebut sama sekali tidak memberikan dampak yang berarti terhadap besaran dana untuk operasional pendanaan oleh BPRS yang berada di Provinsi Jawa Timur bagian untuk wilayah kerja Kantor OJK Regional IV Jawa Timur.

2. Dana dari pihak ketiga, rasio pembiayaan bermasalah, rasio likuiditas bank, rasio profitabilitas bank, terjadinya inflasi serta suku bunga acuan yang berlaku selama kurun waktu tersebut, bersama-sama mempengaruhi besaran dana untuk kegiatan pendanaan yang disalurkan oleh BPRS di Provinsi Jawa Timur yang masuk wilayah kerja Kantor OJK Regional IV Jawa Timur.

Saran yang bisa disampaikan dari penelitian ini untuk kemajuan BPRS antara lain:

1. BPRS agar tetap mampu menjalankan kegiatan pembiayaan dengan baik, adalah dengan memaksimalkan penerimaan DPK, sebab besaran dana untuk pendanaan ke masyarakat bertambah seiring dengan penambahan DPK serta berdasar pula pada hasil penelitian ini yang menyatakan besaran dana dari pihak ketiga cukup berpengaruh terhadap jumlah keseluruhan dana untuk alokasi operasional pendanaan oleh BPR Syariah di Provinsi Jawa Timur pada wilayah kerja Kantor OJK Regional IV Jawa Timur, DPK lebih ditingkatkan lagi.

2. Angka NPF yang masih relatif tinggi tidak akan baik bagi kesehatan bank, kendati penerimaan DPK dan pembiayaan yang terus bertambah. BPRS di Provinsi Jawa Timur yang masuk wilayah kerja Kantor OJK Regional IV Jawa Timur diharapkan lebih ketat dan selektif lagi dalam memberikan pembiayaan kepada nasabah pembiayaan, mengingat pembiayaan yang semakin tinggi akan rentan terhadap risiko gagal bayar oleh nasabah atau pembiayaan bermasalah yang dapat berdampak pula terhadap tingkat likuiditas BPRS.

3. Rasio profitabilitas BPRS (ROA) yang masih tergolong rendah bahkan ada yang dalam kondisi minus, diharapkan BPRS terus berupaya meningkatkan ROA, mengingat ROA penting bagi BPRS dalam mengukur kinerjanya dalam menghasilkan profitabilitas. Kinerja perbankan dalam menghasilkan profit bagi perusahaannya tersebut yang menjadi bahan pertimbangan bagi nasabah pendanaan maupun investor untuk menempatkan dananya.

\section{DAFTAR PUSTAKA}

Annisa, L. N., \& Yaya, R. (2015). Pengaruh Dana Pihak Ketiga, Tingkat Bagi Hasil Dan Non Performing Financing Terhadap Volume Dan Porsi Pembiayaan Berbasis Bagi Hasil Pada Perbankan Syariah Di Indonesia. Share, 4(1), 79-104.

Antonio, M. S. (2001). Bank Syariah Dari Teori Ke Praktik. Jakarta: Gema Insani.

Awaludin. (2017). Inflasi Dalam Prespektif Islam (Analisis Terhadap Pemikiran Al-Maqrizi). Jurnal Imiah Syariah, 16(59), 197-217.

Azmy, A. (2018). Analisis Pengaruh Rasio Kinerja Keuangan Terhadap Profitabilitas Bank Pembiayaan Rakyat Syariah Di Indonesia. Jurnal Akuntansi, Xxii(01), 119-137.

Bakti, N. S. (2018). Analisis Dpk, Car, Roa Dan Npf Terhadap Pembiayaan Pada Perbankan $\begin{array}{llllll}\text { Syariah. Jurnal Bisnis Dan } & 17 .\end{array}$ Https: //Doi.Org/10.20961/Jbm.V17i2.17180

Boediono. (2008). Ekonomi Makro. Yogyakarta: Bpfe-Yogyakarta.

Dendawijaya, L. (2009). Manajemen Perbankan. Jakarta: Ghalia Indonesia.

Destiana, R. (2016). Analisis Faktor-Faktor Internal Yang Mempengaruhi Pembiayaan Usaha Mikro Kecil Dan Menengah ( Umkm ) Pada Bank Syariah Di Indonesia. Jrka, 2(1), 15-28.

Husaeni, U. A. (2017). Determinan Pembiayaan Pada Bank Pembiayaan Rakyat Syariah Di Indonesia. Esensi:Jurnal Bisnis Dan Manajemen, 7(April), 49-62. 
Https://Doi.Org/10.15408/Ess.V7i1.4542

Indonesia, C. (2019). Ojk Cabut Izin Usaha Bpr Syariah Hareukat Aceh Besar. Retrieved January 10, 2020, From Cnn Indonesia Website: Https://Www.Cnnindonesia.Com/Ekonomi/20191011193531-78-438862/Ojk-Cabut-IzinUsaha-Bpr-Syariah-Hareukat-Aceh-Besar

Ismail. (2011). Manajemen Perbankan : Dari Teori Menuju Aplikasi (Cet. 2). Jakrta: Kencana. . (2016). Perbankan Syariah (Pertama). Jakarta: Prenadamedia.

Kamal, F. (2014). Analisis Faktor-Faktor Yang Mempengaruhi Profitabilitas Bank Pembiayaan Rakyat Syariah (Bprs) Di Indonesia Pasca Krisis Keuangan Global Tahun 2008. Jurnal Muamalah, Iv(1), 69-76.

Ma'arifa, S. F., \& Budiyono, I. (2015). Analisis Pengaruh Dana Pihak Ketiga, Sertifikat Bank Indonesia Syariah, Bi Rate, Dan Inflasi Terhadap Pembiayaan Murabahah Perbankan Syariah Di Indonesia Periode 2006-2014. Jurnal Sains Ekonomi Dan Perbankan Syariah, 5.

Nurbiaty, N. (2017). Faktor-Faktor Yang Mempengaruhi Penyaluran Pembiayaan Berbasis Bagi Hasil Pada Bank Syariah Mandiri Indonesia Periode 2003-2015. Jom Fekon, 4, 783-797.

Otoritas Jasa Keuangan. (2019). Statistik Perbankan Syariah September 2019. Https://Doi.Org/10.1017/Cbo9781107415324.004

Ovami, D. C., \& Thohari, A. A. (2018). Pengaruh Dana Pihak Ketiga Dan Non Performing Financing Terhadap Pembiayaan Musyarakah. Jurnal Penelitian Pendidikan Sosial Humaniora, $3(1)$.

Saekhu, S. (2015). Pengaruh Inflasi Terhadap Kinerja Pembiayaan Bank Syariah, Volume Pasar Uang Antar Bank Syariah, Dan Posisi Outstanding Sertifikat Wadiah Bank Indonesia. Economica: Jurnal Ekonomi Islam, 103. Https://Doi.Org/10.21580/Economica.2015.6.1.788

Sudana, I. M. (2009). Manajemen Kenangan. Surabaya: Airlangga University Press.

Umam, K., \& Utomo, S. B. (2017). Perbankan Syariah (Dasar-Dasar Dan Dinamika Perkembangannya Di Indonesia) (1st Ed.). Jakarta: Rajagrafindo Persada.

Umiyati, \& Ana, L. T. (2017). Faktor-Faktor Yang Mempengaruhi Pembiayaan Pada Bank Umum Syariah Devisa Di Indonesia. Jurnal Ekonomi Dan Perbankan Syariah, 5.

Wahiddudin, M. (2018). Pengaruh Inflasi, Non Performing Finacing (Npf) Dan Bi Rate Terhadap Pembiayaan Usaha Mikro Kecil Dan Menengah (Umkm) Pada Bank Umum Syariah 20122017. Al Amwal, 1(1), 76-89.

Wardiantika, L., \& Kusumaningtias, R. (2014). Pengaruh Dpk, Car, Npf, Dan Swbi Terhadap Pembiayaan Murabahah Pada Bank Umum Syariah Tahun 2008-2012. Jurnal Ilmu Manajemen, 2,1550-1561.

Widiastuty, T. (2017). Faktor-Faktor Yang Mempengaruhi Volume Pembiayaan Berbasis Bagi Hasil Pada Perbankan Syariah Di Indonesia. Jumal Mitra Manajemen, 21(1), 1-12. Https://Doi.Org/10.34208/Jba.V19i1.60

Widyaningrum, L., \& Septiarini, D. F. (2015). Pengaruh Car, Npf, Fdr, Dan Oer Terhadap Roa Pada Bank Pembiayaan Rakyat Syariah Di Indonesia Periode Januari 2009 Hingga Mei 2014. Journal Jestt, 2(12), 970-985. 